\title{
ECONOMY
}

\section{ESSENCE OF ECONOMICAL SAFETY SYSTEM OF FUEL AND ENERGY COMPLEX AS ONE OF THE TYPES OF A COMPLEX SOCIAL-ECONOMICAL SYSTEM}

\author{
Dmytro Busariev, $P h D$ \\ State educational-scientific institution "Academy of Financial Management», Kyiv, Ukraine
}

DOI: https://doi.org/10.31435/rsglobal_ws/31052019/6518

\section{ARTICLE INFO}

Received: 28 March 2019

Accepted: 20 May 2019

Published: 31 May 2019

\section{KEYWORDS}

security, economic security, complex social-economical system, fuel and energy complex, system.

\begin{abstract}
The main purpose of the article is to define the essence of the economic security system of the fuel and energy complex. The essential features of the concept «system» are defined. The concept of «system of economic security» in the context of essential features has been formed as a divergence. The main approaches to the interpretation of the concept of «economic security system» are defined. The interdependence of the hierarchy of goals of the economic security system of a complex socioeconomic system is determined.
\end{abstract}

Citation: Dmytro Busariev. (2019) Essence of Economical Safety System of Fuel and Energy Complex as One of the Types of a Complex Social-Economical System. World Science. 5(45), Vol.3. doi: 10.31435/rsglobal_ws/31052019/6518

Copyright: (C) 2019 Dmytro Busariev. This is an open-access article distributed under the terms of the Creative Commons Attribution License (CC BY). The use, distribution or reproduction in other forums is permitted, provided the original author(s) or licensor are credited and that the original publication in this journal is cited, in accordance with accepted academic practice. No use, distribution or reproduction is permitted which does not comply with these terms.

Introduction. Complex social-economical systems have a significant influence on the state of national economy and have some character differences in their structure that others do not have- One of those is «bipolarity» from one side we have a system of an open type but from the other practically total subordination in functions and in development, that is conducted by a system of a higher order. One of those systems - fuel and energy complex.

Because of political volatility fuel and energy complex of Ukraine is very sensitive to any external and internal threats. In order to adapt and resist an effective system of economic safety is needed. Integration of existing system of an economical safety would not be enough because the specifics of functioning requires a new approach that will take into consideration structural specifics of a social-economical system which is fuel and energy complex today. That is why the research of the essence of a system of economic safety in connection with complex social and economic systems as fuel and energy complex.

Research results. Systemicity is an integral part of scientific cognition of the world by a person. For example, as Brorschuk E.M. states, systemicity can be perceived as an explanatory rule of scientific understanding that requires learning of the process in connection with structural unity of the subject that is being studied thanks to what it acquires new characteristics [1, c.64].

A central place in the systemicity is taken by a term «system». Derived from a Latin word it means «connection», that is actually a whole that consists of a certain quantity of several parts.

Essential characteristics of the term «system» are represented on an fig. 1.

So, in our opinion under the term «system», we should understand a certain summation of objects that form one holistic organism through the interdependence and close interaction between themselves.

In practical identity to the notion of "system», the system of economic security regards Prokhorov V.V., Prokhorov Yu.V., Kucherenko O.O. [2, p.24-25]. They believe that the system of economic security - is a set of interrelated elements that form a single whole. 


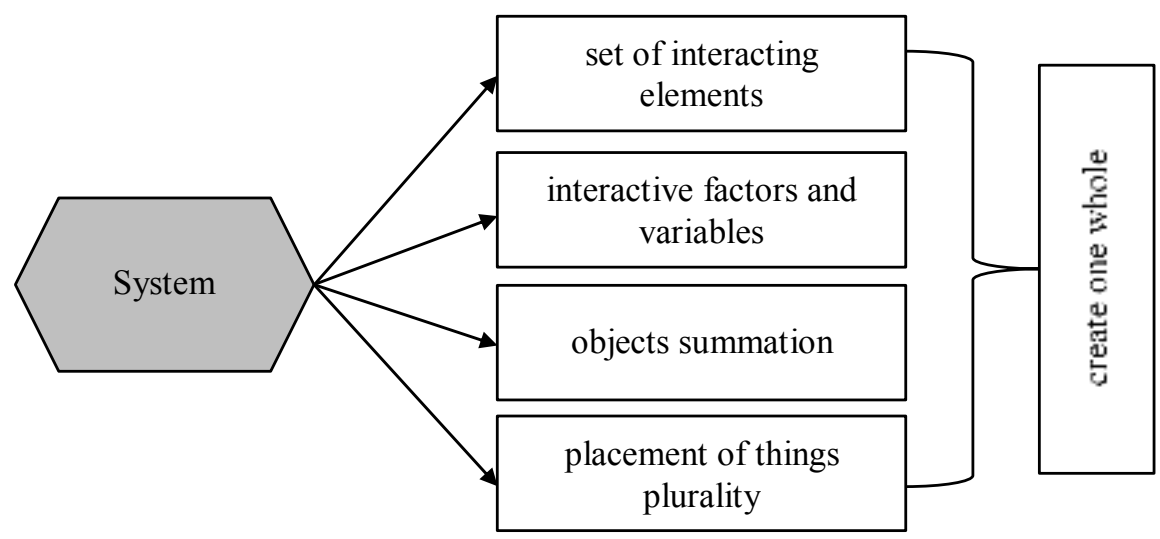

Fig. 1. Essential characteristics of the term «system»

Kirichenko O., Alkema V.G. [3, p.8] emphasize that the system of economic security is a complex economic system, with a large number of structural elements. But, in our opinion, it is also important to consider the social component and therefore the system of economic security should include in its structure the elements that are inherent in the socio-economic system.

We conducted the divergence of the essence of the concept of «system of economic security» (Fig.2).

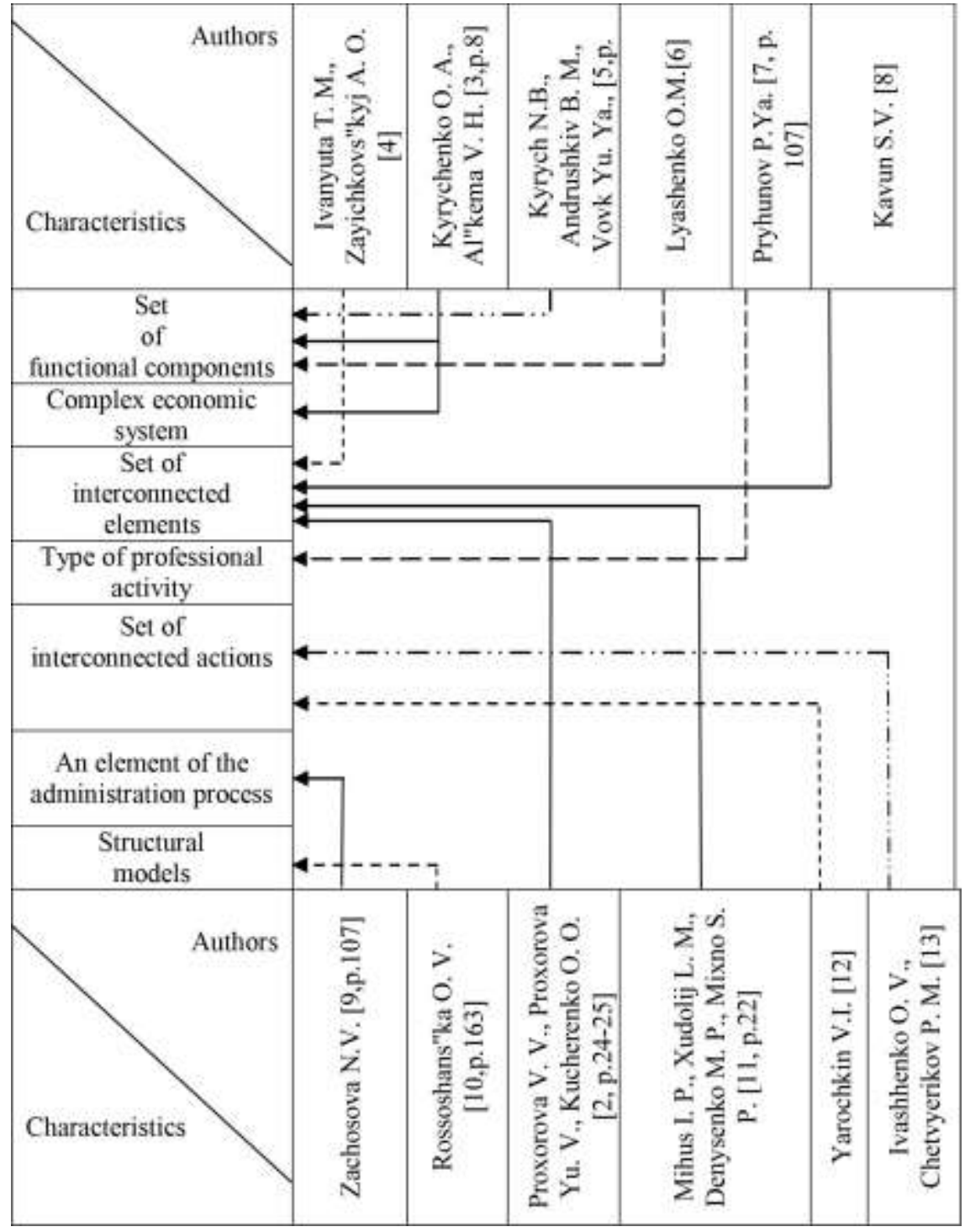

Fig. 2. divergence of the essence of the concept of «system of economic security» 
The divergence of the essence of the notion of «system of economic security» allowed us to formulate basic approaches to the interpretation of this concept. We can distinguish the following approaches to the interpretation of the concept of «system of economic security»: (Table 1).

Summing up our conducted analysis, we believe that under the system of economic security we must understand the totality of structural elements that are closely interconnected and interact with each other, in order to ensure the security of the socio-economic system.

Table 1. Main approaches to the interpretation of the concept of «system of economic security»

\begin{tabular}{|c|l|}
\hline Approaches & \multicolumn{1}{|c|}{ Essence } \\
\hline Administrative & $\begin{array}{l}\text { system of economic security is nothing else but a part of the main } \\
\text { administrative process }\end{array}$ \\
\hline Protective & $\begin{array}{l}\text { system of economic safety is aimed at protection of the social-economical } \\
\text { system against internal and external threats }\end{array}$ \\
\hline Procedural & $\begin{array}{l}\text { system of economic safety is a process that anticipates the realization of a } \\
\text { certain totality of actions with the aim of providing safety }\end{array}$ \\
\hline Structural & system of economic safety is a unity of structural elements that form a whole \\
\hline
\end{tabular}

Proceeding from the proposed definition and conducted analysis of the essence of the concept of «economic security of a complex socio-economic system», we believe that under the system of economic security of a complex socio-economic system (for example, the fuel and energy complex) should be understood as a set of structural interconnected and interacting elements that are directed to identify challenges, minimize risks, counteract (adapt) external and internal threats and dangers in order to achieve social, economic and energy security.

The purpose of the system of economic security of the fuel and energy complex is to form a system of protection of economic, social, and environmental interests of not only this complex as a whole, but also of each socio-economic system in its composition separately and of a state that acts as a supreme level of governance.

With regard to the aims that are intended to achieve the goal, the main feature is their hierarchy.

With a systematic approach, [14] uses such a hierarchical division of objectives for strategic, tactical and operational.

For a complex socio-economic system, which includes a fuel and energy complex, such a hierarchical division of objectives, also, can be considered acceptable, but taking into account certain features inherent in this type of system (Fig. 3).

Strategic goals of the economic security system of a complex socio-economic system envisage solving large, large-scale problems that impede the achievement of the goal.

The intermediate aims for strategic goals are tactical ones, which are aimed at separate problems, the solution of which will contribute to achieving both strategic aims and a goal as a whole.

The operational objectives of the economic security system of a complex socio-economic system are those goals that are put and resolved every day to ensure security and achieve tactical goals, respectively.

It should be noted that all goals are closely interlinked with the strategic, tactical and operational goals of each socio-economic system that is part of it. Therefore, achieving the strategic goals of each socio-economic system as part of a complex will lead to achievement and its goals accordingly. In addition, they must be consistent with the goals of public administration, since such systems, such as the fuel and energy complex, are subject to the function not only of direct management but also of the higher-level system, the state.

Conclusions. In 25 years of existence of our state, management of such complex socioeconomic systems as the fuel and energy complex has not changed. There is still vertical control of a state, which on the one hand indicates a high level of control, but on the other, there is no development due to the non-application of new management methods.

Economic security in the conditions of complex socio-economic systems requires the creation of such a system that will allow reconciling interests not only within this complex system but also with a higher level, that is, the state. If considered in the context of such a complex system as a fuel and energy complex, then not only the achievement of economic interests but also social and environmental considerations should take into consideration the specifics of an activity. 


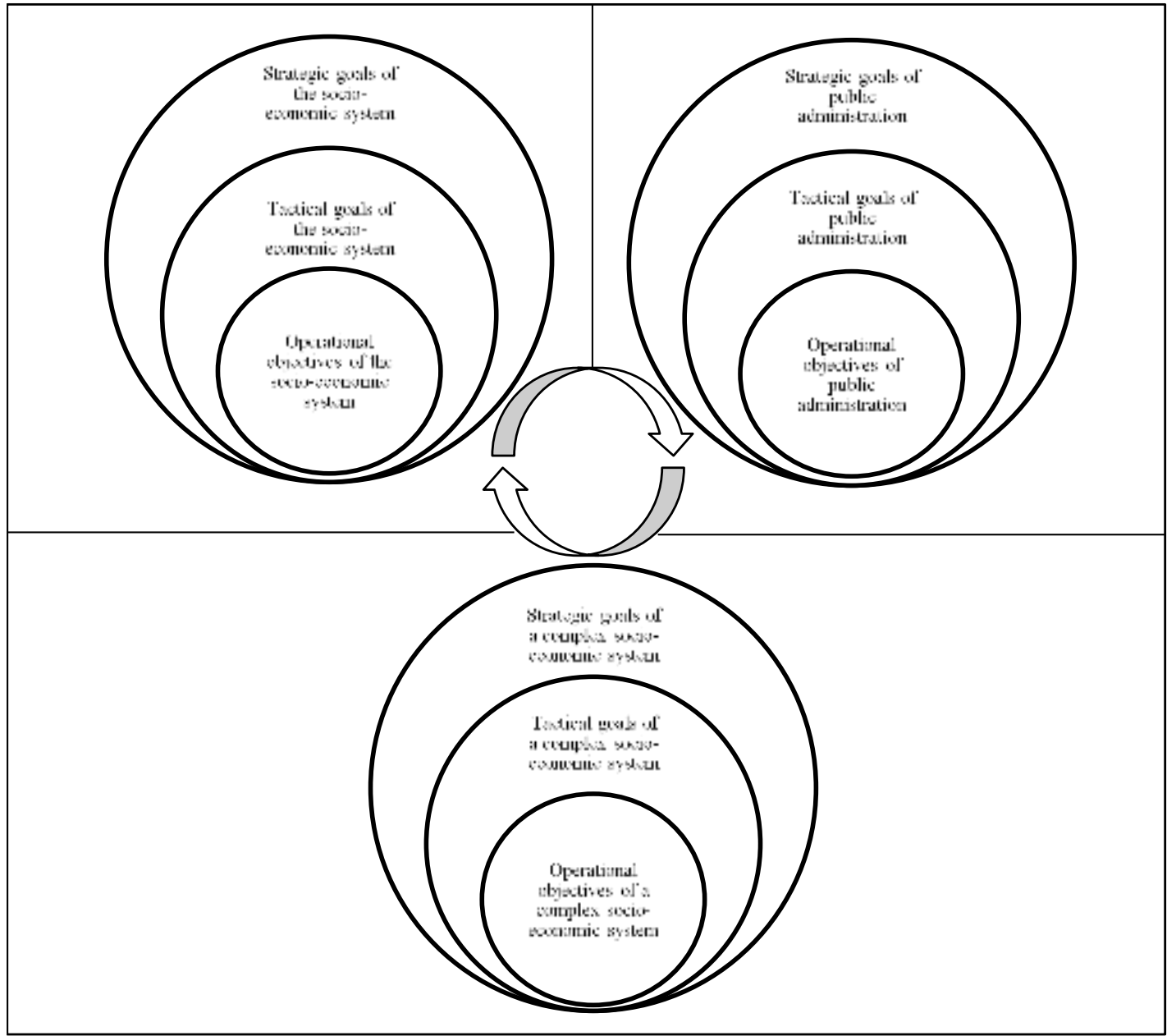

Fig.3. The interdependence of the goals hierarchy of economic security system of a complex socioeconomic system

\section{REFERENCES}

1. Borshchuk Ye. M. Teoretyko-metodolohichni osnovy systemnoho analizu staloho rozvytku ekolohoekonomichnykh system: dys. ... doktora ekon. nauk: 08.00.06 / Borshchuk Yevhen Mykhailovych. [Theoretic-methodological basics of a systematic analysis of the development of ecologic-economical system] - Lviv, 2009. - $352 \mathrm{p}$.

2. Prokhorova V. V., Prokhorova Yu. V., Kucherenko O. O. Upravlinnia ekonomichnoiu bezpekoiu pidpryiemstv: monohrafiia. [Management of ecological safety of companies] Kharkiv: UkrDAZT, 2010. 282 p.

3. Kyrychenko O. A., Alkema V. H. Kontseptualni zasady formuvannia systemy ekonomichnoi bezpeky v umovakh hlobalizatsii. [Conceptual basics of formation of an economical safety in a period of globalization]. Aktualni problemy ekonomiky. 2010. № 12/114. P. 6-18.

4. Ivaniuta T. M., Zaichkovskyi A. O. Ekonomichna bezpeka pidpryiemstva: navch. posib. dlia stud. vyshch. navch. zakl. [Economic safety of an enterprise]. Kyiv: Tsentr uchbovoi literatury, 2009. 256 p.

5. Ekonomichna ta mainova bezpeka pidpryiemstva i pidpryiemnytstva. [Economic and financial safety of enterprises and entrepreneurship]. Antyreiderstvo: monohrafiia / N. B. Kyrych, B. M. Andrushkiv, Yu. Ya. Vovk ta in. Ternopil: Terno-hraf, 2008. 424 p.

6. Liashenko O.M. Kontseptualizatsiia upravlinnia ekonomichnoiu bezpekoiu pidpryiemstva: [monohrafiia] / O.M. Liashenko. [Conceptualisation of management of economical safety of an enterprise]. - Luhansk: vyd-vo Snu im. V. Dalia, 2011. -400 p.

7. Pryhunov, P.Ia. Osoblyvosti vykorystannia suchasnykh kontseptsii upravlinnia v systemi zabezpechennia ekonomichnoi bezpeky pidpryiemstv. [Special characteristics of usage of concepts of management in a system of arrangement of economical safety]. / P.Ia. Pryhunov // Yevropeiski perspektyvy. - 2013. - № 11. - P. 103-108.

8. Kavun S. V. Systema ekonomichnoi bezpeky: metodolohichni ta metodychni zasady: monohrafiia. [System of economical safety]. Kharkiv: KhNEU, 2009. 300 p.

9. Zachosova N.V. Upravlinnia systemoiu ekonomichnoi bezpeky finansovykh ustanov. [Administration of a system of economical safety of financial institutions]. dys. dok. ekon. nauk: 21.04.02. Kyiv.2017. 603 p. 
10. Rossoshanska O. V. Sutnist ekonomichnoi bezpeky subiektiv hospodariuvannia yak sfery ekonomichnoi nauky. [Essence of economical safety of enterprises as a sphere of economic studies]. Upravlinnia proektamy ta rozvytok vyrobnytstva. 2011. № 2 (38). P. 161-166.

11. Korporatyvne upravlinnia $\mathrm{v}$ systemi ekonomichnoi bezpeky aktsionernykh tovarystv Ukrainy: monohrafiia / [Corporate management in a system of economic safety of AT]. I. P. Mihus, L. M. Khudolii, M. P. Denysenko, S. P. Mikhno. Cherkasy: TOV «Maklaut», 2012. 274 p.

12. Iarochkin V.I. Sekiutyrolohiia - nauka pro bezpeku zhyttiediialnosti. [Secutorology the science of safety of livelihood]. / V.I. Yarochkin. [Elektronnyi resurs]. - Rezhym dostupu: http://kievsecurity.org.ua/b/x22/index.shtml.

13. Ivashchenko O. V., Chetvierikov P. M. Systema finansovo-ekonomichnoi bezpeky pidpryiemstva. [System of financial-economical safety of an enterprise]. «Scientific researches and their practical application. modern state and ways of development 2012»: materialy Mizhnar. nauk.-prak. internet-konf. URL: http://www.sworld.com.ua/konfer28/51.pdf

14. Shehda A. V. Menedzhment: navch. posib. / [Management]. A. V. Shehda. - K.: Znannia, 2002. - 583 p. 